Quarter (2019)

\title{
ANSERJ
}

Vol. 10 , No. 2

Autumn / Automne 2019

pp. $77-80$

Canadian Journal of Nonprofit and Social Economy Research

Revue canadienne de recherche sur les OBSL et l'économie social

\section{My Life and My Work, in Brief ${ }^{1}$}

\author{
Jack Quarter
}

\section{FOREWORD}

Jack Quarter passed away on February 6, 2019, after a brief illness. Jack was always generous with his time and would offer support to anyone who had the occasion to speak with him. While many have primarily known him by his research and theory building concerning the social economy, his path and what has influenced him are less clear. In December 2018, Dale Willows (his partner of 32 years) and I encouraged him to write a brief autobiography, and what appears below is the outcome.

Upon reading his words, I felt that Jack's journey contains much to learn from and is quite forward-thinking in many respects. Thus, rather than providing an in memoriam in this issue, I offer the reader this opportunity to learn about his path. I encourage you to ask yourself a few questions as you read this brief autobiography: How did you become interested in social economy and nonprofit studies or research? How has your current work and perspective been influenced by your path? Jack was never shy to share parts of his history, and it is a privilege to be able to share a part of his story with you.

\section{AVANT-PROPOS}

Jack Quarter est décédé le 6 février 2019 à la suite d'une brève maladie. Jack était toujours généreux de son temps et il offrait son appui à toute personne ayant l'occasion de converser avec lui. Plusieurs l'ont connu principalement par sa recherche et sa formulation de théories en économie sociale sans forcément savoir quel était son parcours et ses influences. En décembre 2018, Dale Willows (son partenaire pendant 32 ans) et moi l'avons encouragé à rédiger une brève autobiographie. II en a résulté le texte que vous voyez ci-dessous.

En lisant ses paroles, j'ai senti qu'on peut en apprendre beaucoup en suivant le parcours—visionnaire à bien des égards— que Jack a suivi. Conséquemment, plutôt que d'inclure une eulogie dans ce numéro, j'offre aux lecteurs et lectrices l'occasion d'en apprendre un peu sur son parcours. Pendant votre lecture de cette brève autobiographie, je vous encourage à vous poser quelques questions: qu'est-ce qui vous a motivé à vous intéresser aux études ou à la recherche sur les organismes sans but lucratif et l'économie sociale? Comment votre propre parcours a-t-il influencé vos perspectives et votre travail actuels? Jack n'a jamais reculé devant le partage de son histoire, et c'est pour moi un privilège de pouvoir partager le texte suivant avec vous.

Jorge Sousa

November, 2019

doi: 10.29173/anserj.2019v10n2a341 


\section{Quarter (2019)}

I come from a very unusual background. My school beginnings were on the rough side. If it were not for a psychologist armed with an IQ test, I might still be in kindergarten. However, things picked up from there, and I was only 12 when I entered Harbord Collegiate Institute, my age being a mixed blessing as I was immature.

My family had two religions, Judaism, which was primarily a cultural activity (e.g., attending Camp Yungvelt), and Communism, which was the real thing. When other Jewish boys were preparing for their Bar Mitzvahs and learning text such as Barukh ata Adonai Eloheinu, melekh ha'olam, I was reading a book that started with, "A spectre is haunting Europe - the spectre of communism," (Mark, 1954, p. 8). and ended with, "The proletarians have nothing to lose but their chains. They have a world to win. Workers of the world, unite!" (p. 54).

In my family, Marxism was serious stuff. In the 1920s, my aunt, uncle, and cousin returned to Moscow to be part of the revolution. (Your eyes are not playing tricks on you.) When Joe Stalin died, my grandfather was slumped over his radio, listening to the broadcast, disconsolate, with tears streaming down his face. I was 11 years old and trying to make sense of the conflicting signals from the world around me and my family.

As a young lad, Judaism and Communism seemed radically different, but as I matured it became apparent that they were much the same: one prophesizing a heaven after earth for adherents and the other prophesizing heaven on Earth, and even more so believing that Marx, the prophet who ironically came from a lengthy rabbinical tradition, had proven scientifically how heaven on Earth would come about. Both were faith-based systems, and both were rife with dogmatism, especially if taken seriously.

My father was a heroic figure in my life, especially in my formative years; he was a dress cutter and labour organizer, was critical of Stalinism, but maintained the faith as a Trotskyist. Nevertheless, there was a pragmatic side to him, and in his later life he was primarily a social democrat. My dad worked long hours and attended union meetings following work, but he always made time for my brother and myself. I relished our chess games. Saturday afternoon at 1 p.m. was opera time and time for me to head out, but some of it stuck, as I now enjoy the opera.

I credit Peter Russell, a brilliant young lecturer at the University of Toronto ( $U$ of $T$ ) in my first course in political science, with helping me to understand that there were middle ways in politics and not everything need be reduced to extremes. I was searching, needing ideals, and was a bit unhinged. At first the study of psychology, Freud, and Fromm became an escape, and I completed an MA in social psychology at the $U$ of $T$, after turning down an offer from the $U$ of $T$ Law School. I did my PhD at the Ontario Institute for Studies in Education (OISE) at the $U$ of $T$, with a thesis on the student movement of the sixties, which was published as a book in 1972, the year my daughter, Zoey, was born.

However, I was still searching. I had a yen, a human yearning to see a better way. In 1980 , I had a sabbatical from my faculty position at OISE and took the unusual step of living on a kibbutz, a utopian communal system in Israel that I had studied and wanted to learn more about. It also gave me a chance to introduce my children to a secular form of Judaism, apart from religious worship. This was a life-changing experience for me, as I was introduced to a form of co-operative that seemed to work and offered its members a good standard of living and a good quality of life. It also gave my family and me an opportunity to experience Judaism as a living culture without all the religious baggage.

One of the most astonishing observations for me when we arrived at the kibbutz was the restlessness of the younger generation. While the founders believed they had created heaven on Earth, their children were searching for change, and in doing so were encouraged by their elders; the elders urged them to travel and see the rest of the world, believing they would return because the kibbutz was such a superior society. I wrote several papers on the topic, including 


\section{Quarter (2019)}

"Intergenerational Discontinuity in the Israeli Kibbutz." (Quarter, 1984). The kibbutz was an open society with an educational system that emphasized individual choice, and it resulted in fundamental changes to its communal structure, something that I later wrote about in the book Crisis in the Israeli Kibbutz, which I edited with my dear colleagues and friends Uri Leviatan and Hugh Oliver. (Leviatan, Quarter, \& Oliver, 1998)

One observation that stuck with me from our stay at Kibbutz Ein Hamifratz was that when the assembly line for the huge agricultural carton factory broke down, the workers would rush to fix it. I had worked on assembly lines during summer jobs, and when the line broke, the religious among the group would look skyward and offer a large thank you. No one rushed to fix it. I felt that I was witnessing a new model of work, and when we returned to Toronto, I immersed myself in the study of co-operatives and particularly worker co-operatives, firms that were owned in common and democratically managed by their employees.

My interests were not simply about democratic forms of work management but also about how wealth could be distributed more equitably, not only using government policies but also through firms, pensions, and union initiatives. My interests gradually expanded, and I began to see co-operatives as part of a wider social sector: the social economy. As I studied more, I became astonished at how broad Canada's social economy was and that co-operatives were such a small piece of it. The beginning of this work was my 1992 book, Canada's Social Economy: Co-operatives, Non-profits and Other Community Enterprises. The book was the first comprehensive portrait of Canada's social sector.

A consistent theme running through this work is that our economy is mixed, and the organizations in the social economy interact with the private and public sectors in differing ways. We used a Venn diagram to portray these differing interactions. Some secondary themes sprang from this research, such as a strong interest in volunteering and how to measure it, led by my colleague Laurie Mook of Arizona State University. One of the greatest pleasures in my work is sharing with past and current students. I have been blessed by the students who have found me, and they have greatly enriched my life. Many now teach at universities in Canada and the United States. I have been fortunate.

A common denominator in my work is faith in a better way, possibly a form of religious belief, but one that gives my life's work meaning. One of my struggles in life and in my work has been to maintain a balance between idealism and pragmatism. To this I credit my beloved partner of 32 years, Dale Willows, who has modelled for me how this could be done. We share many of the same ideals, but she has helped me to stay balanced and carefully consider evidence before formulating opinions. Part of my motivation for doing this is to try and model that balance for my beloved son, David, of whom I am very proud.

My life has been about much more than work. I have derived immense pleasure from riding my bicycle along the Galloping Goose Trail on Vancouver Island; I enjoy losing myself in a bridge game, usually on Sunday evenings, though I sadly lost my bridge partner and longtime friend, Hugh Oliver. I can lose myself in a good book, particularly political biographies, and enjoy music of all sorts, with a special nod to Leonard Cohen, perhaps because like me he sings off-key. I have been blessed with a loving family and a strong circle of friends.

I write this at age 77, struggling with advanced stomach cancer and an uncertain future. Like most people I have some regrets: not knowing my mother; my daughter's death at age 34 from breast cancer; not having children with Dale Willows. I dabbled with creative writing at various points, writing a play, Reflections of a Well-Conditioned Madman, that the BBC put on in 1979 (Quarter, 1979). I would have liked to publish that great novel, but I never did. Nevertheless, I have been very fortunate in my life-personal and work_and hope that I have contributed in some small way. In spite of the many problems in this world, I remain hopeful that people will find a better way.

Jack Quarter, January 2019 


\section{Quarter (2019)}

\section{NOTE}

1. This piece was written by Jack Quarter and appears on a website that was created in his memory, www.jackquarter.org, which you are encouraged to visit. The content contains minor edits for style and publication.

\section{REFERENCES}

Leviatan, U., Quarter, J., \& Oliver, H. (Eds.). (1998). Crisis in the Israeli kibbutz: Meeting the challenge of changing times. Westport, C.: Greenwood/Praeger Publishing.

Marx, K. (1954). The Communist manifesto. Chicago, IL: H. Regnery.

Quarter, J. (Writer). (1979, April 9th). Reflections of a well-conditioned madman or mind over matter. In Thirty Minute Theatre. London, UK: British Broadcasting Corporation. URL: https://www.jackquarter.org/creative-writing [November 20, 2019].

Quarter, J. (1984). Intergenerational discontinuity in the Israeli kibbutz. Journal of Educational Thought in Collective Settlements, 114, 31-53.

Quarter, J. (1992). Canada's social economy: Co-operatives, non-Profits and other community enterprises. Toronto, ON: Lorimer. 